\title{
THE SOLAR ENERGY AS UNDERSTOOD FROM SATMBAPURĀNA
}

\author{
Dr. V. Yamuna Devi
}

\begin{abstract}
The ancient seers have observed nature closely and have recorded their observations in the Vedas and Purānas. Sun is the main source of light and energy to planet earth. The various aspects of Sun and its mode of worship has been dealt with in the Purānas. This paper brings to notice some of the aspects of sun which have been specifically termed to be the cause of energy and change in environmental conditions on earth and other planets. The Sambapurāna is the prime source of the information for this paper.
\end{abstract}

\section{INTRODUCTION :}

The Purāna literature is vast and in large numbers. The Purānas are grouped as Mahapurānas and the Upapurānas with eighteen principal ones in each classification. Based on the principal deity dealt with in the Purānas, they are further grouped as Saurapurānas dealing with Sun, Sāktapurāṇas - with the Goddess as the Supreme, Gānapatya - Lord Ganesa as the principal God, Śaiva - Śiva as the Highest Lord, Vaiṣnava - Viṣnu as the Supreme Deity and Kaumāra - Kumāra as the Supreme.

The Sun worship exists from the Vedic times. The yearly Sankkānti is celebrated in the month of Pauṣa throughout India when the Sun starts moving northwards from the tropic of Capricorn. The Sundays of the Śrāvana month are dedicated to Sun-worship. The famous Sun temple at Konark also remains as a 
place of the Saura worship. Some Purānas describe in detail the worship of Sun while a few deal briefly about it.

Today science has developed to such an extent that the solar energy is trapped and utilised for various purposes especially in generating electricity. Further it is discovered that there are many rays like the ultra violet ray which are harmful with direct exposure during intense summers but put to use effectively in medical field. Similarly the Vitamin D - indispensable for human health especially the bones, is available exclusively in the Sun's rays alone. These are the general facts known about the Sun's rays in recent times.

\section{SUN IN THE SĀMBAPURĀNA}

The Purānas though dedicated to a particular cult as Śākta or Saiva, deal with all the subjects. The description of Sun, it's size, various rays, names of different months and seasons etc presented in Purānas reveal that the sages of ancient times have made a deep study of nature around them. Sun worship and description of Sun can be found in most Purānas in a few chapters. The Bhavișya, Agni, Garuḍa, Viṣnudharmottara, Bhaviṣyottara, Kālikā, Mārkaṇdeya and other Purānas have extracts on the various aspects of Saura cult. Of all the Purānas extant, the Sāmbapurāna is the only one that deals principally with the Saura worship. Thus the present paper culls out information about Sun and Solar energy from the Sāmbapurāna.

The Sämbapurāna $a^{1}$ records that the Supreme Lord Sūrya took the form of twelve Ādityas. The twelve Ādityas are Indra, Dhātā, Parjanya, Pūṣā, Tvașțā, Aryamā, Bhaga, Vivasvān, Viṣnu, Amśu, Varuna and Mitra:

ततः स च सहस्रांशुरव्यक्तः पुरुषः स्वयम्।

कृत्वा द्वाद्राधात्मानमादित्यमुद्पद्यत॥

इन्द्रो धाताऽथ पर्जन्यः पूषा त्वष्टाऽर्यमा भगः।

विवस्वान् विष्णुरंराश्च वरुणो मित्र एव च॥ 
Of these twelve Âdityas, Indra is said to lead the Gods; Dhātā is the creator; Parjanya exists in the clouds and showers rain; Pūṣā exists in the food nourishing all the living beings; Tvaștā presides over the plants and herbs; Aryamā is responsible for the movement of air; Bhaga exists in the bodies of living beings; Vivasvān assumes the form of digestive fire in living beings; Viṣnu takes various forms to destroy the enemies of the gods; Amśa existing as the winds pleases all beings; Varuna enters the water as the life energy and Mitra as the sun, gives light and energy to the world.

\section{THE RAYS NOURISHING THE STARS AND PLANETS :}

Sāmbapurāna ${ }^{2}$ states that there are seven important rays which nourish the planets and stars :

सुषुम्नः सूर्यररिमर्यः क्षीणं शारिनमेधते ।

सम्यग्वासुस्तु यो रईिमर्योनिः सोऽ दारकस्य तु ॥

दक्षिणे विरवकर्मा तु ररिमराप्यायते बुधमू।

उदावसुस्तु यो ररिमर्योनिः स तु बृहस्पतेः॥

विरवव्यचाइच यो ररिमः शुक्रयोनिः स वै स्मृतः।

रानैइचरं पुनरचापि रहिमराप्यायते सुराट्॥

हरिकेरास्तु यो ररिमर्जेयो नक्षत्रयोगिनः।

As gleaned from the verses cited above the different types of rays and the planets that they support are given in the table:

$\begin{array}{ll}\text { Rays } & \text { Planet/ Stars } \\ \text { Suṣumnā } & \text { The moon } \\ \text { Samyagvasu } & \text { Lohita (Mars) } \\ \text { Viśvakarmā } & \text { Budha (Mercury) } \\ \text { Udāvasu } & \text { Bṛhaspati (Jupiter) } \\ \text { Viśvavyacā } & \text { Śukra (Venus) } \\ \text { Surāt } & \text { Śanaiścara (Saturn) } \\ \text { Harikeśa } & \text { The stars }\end{array}$


The distance of the planets from the sun varies and hence the intensity, angle and other aspects influence the ray's component ratio which is observed by our seers and hence termed particularly.

Different bodies of the Solar System receive light of an intensity inversely proportional to the square of their distance from Sun. The actual brightness of sunlight that would be observed at the surface depends also on the presence and composition of an atmosphere. For example, Venus's thick atmosphere reflects more than $60 \%$ of the solar light it receives. Sunlight on Mars would be more or less like daylight on Earth during a slightly overcast day, and, as can be seen in the pictures taken by the rovers, there is enough diffuse sky radiation that shadows would not seem particularly dark. Thus, it would give perceptions and "feel" very much like daylight on the Earth. The spectrum on the surface is slightly redder than that on Earth, due to scattering by reddish dust in the Martian atmosphere.

\section{RAYS AND THEIR VARIED EFFECTS :}

The Sammbapurāna $a^{3}$ states that the rain causing rays are collectively called Amrtas, which are four hundred in number with the following names-Vandanās, Medhyās, Kātanas and Ketanas. The rays that cause hima (snow) are yellow coloured, thirty in number and are called Candras. The rays that nourish the men through the food are Aușadhas(herbs), which nourish the Pitrss(manes) are Svadhā and gods are Amrta(nectar):

तासां चतुःःरातं नाडयो वर्षन्तेऽचिन्त्यमूर्तयः।

वन्दनाइचैव मेध्याइच कातनाः केतनास्तथा॥

अमृता नामतः सर्वा रइमयो वृष्टिसर्ज्जनाः।

हिमावहास्तु त्रिंराद्वे ताभ्योऽन्या रइमयः स्मृताः ॥

चन्द्रास्ता नामतः सर्वाः पीताभास्तु गभस्तयः।

समं बिभ्रति ताः सर्वान् मनुष्यान् देवताः पितृन्।

मनुष्यानोषधीभिस्तु स्वधया च पितृनपि ॥

अमृतेन सुरान् सर्वास्त्र्यस्त्रिभिरतर्पयन्। 
The various rays of the sun and thair numbers found in each season is also recorded in the Puranna $a^{4}$ : In the vasanta (spring) and grīṣma (summer) He shines with six rays; in the sarad (autumn) and varșa (rainy seasons) He causes the rains with four of his rays; in hemanta (winter) and in sissira (cold season) He emits the dew with only three of his rays:

वसन्ते चैव ग्रीष्मे च रांतैः सः तपति विभुः॥

रारत्सु चैव वर्षासु चतुर्भिः संप्रवर्षति।

हेमन्ते रिशिरे चैव हिमोत्सर्ग त्रिभिः पुनः॥

THE TWELVE SUNS IN-CHARGE OF EACH MONTH OF THE YEAR :

The twelve Âdityas shining in the twelve months and the number of their rays are recorded in the Sammbapurān $n a^{5}$ :

उत्तिष्ठन्ति सदा ह्येते मासैद्वाद्राभिः क्रमात्।

विष्णुस्तपति चैत्रे तु वैशाखे चार्यमा तथा।

विवस्वाज्ज्येष्ठमासे तु आषाढे चांशुमान् स्मृतः।

पर्जन्यः श्रावणे मासे वरुणः प्रौष्ठसंज्ञके॥

इन्द्रोऽथाइवयुजे मासे धाता तपति कार्तिके।

मार्गशीर्षे तथा मित्रः पौषे पूषा दिवाकरः॥

माघे भगस्तु विज्ञेयस्त्वष्टा तपति फाल्गुने।

In accordance with the above details, the Purāna $a^{6}$ also adds the number of rays of the sun that reach the planet earth in each month of the year. Further it records that during the northern solstice the solar radiation increases and during the southern solstice it decreases; they vary in each month and season :

एतैद्वाददराभिर्विष्णूररमीनां दीप्यते सदा।

दीप्यते गोसहस्तेण इातैइच त्रिभिरर्यमा।

द्विसप्तकैर्विवस्वांस्तु ह्यंशुमान् पश्चकैस्त्रिभिः ॥

विवस्वानिव पर्जन्यो वरुणइचर्यमा यथा।

इन्द्रस्तु द्विगुणेः षड्रभिधातैकाद्राभिः इातैः ॥ 
मित्रस्तु दूराभिः सार्ध पूषा तु दर्शाभिः रांतैः।

मित्रवच्च भगस्त्वष्टा सहस्रेण शातेन च॥

उत्तरोपक्रमेऽर्कस्य वर्द्धन्ते रइमयस्तथा।

दक्षिणोपक्रमे तस्य ह्रसन्ते सूर्यररमयः॥

एवं रईिमसहस्त्र तत् सूर्यलोकार्थसाधकम्।

भिद्यते ऋतुमासाभ्यां सहस्तं बहुधा पुनः॥

These records as given above are represented in the chart below :

$\begin{array}{lll}\text { Ādityas } & \text { Month } & \text { No. of } \\ \text { Viṣnu } & \text { Caitra } & 9,000 \\ \text { Aryamā } & \text { Vaiśākha } & 1300 \\ \text { Vivasvān } & \text { Jyeșṭha } & 1400 \\ \text { Amśumān } & \text { Āṣāọha } & 1500 \\ \text { Parjanya } & \text { Śravaṇa } & 1400 \\ \text { Varuṇa } & \text { Bhādra } & 1300 \\ \text { Indra } & \text { Āśvina } & 1200 \\ \text { Dhātā } & \text { Kārttika } & 1100 \\ \text { Mitra } & \text { Mārgaśirśa } & 5,000 \\ \text { Pūṣā } & \text { Pauṣa } & 1000 \\ \text { Bhaga } & \text { Māgha } & 5000 \\ \text { Tvaștāa } & \text { Phālguna } & 1100\end{array}$

From the above table it can be understood that the ancient seers were aware of the different types of rays of the sun and their numbers. In modern days, the pyranometer or the pyrheliometer is used to measure the rays of the sun. But the instruments used by the ancient Indians are not mentioned in the Purañas or any other text. 
In modern research it is understood that the total amount of energy received at ground level from the Sun at the zenith depends on the distance to the Sun and thus on the time of year. It is about $3.3 \%$ higher than average in January and 3.3\% lower in July.

The Sāmbapurāna $a^{7}$ also describes the sun to have a particular colour in each season. It is further stated that these are the natural colours of the sun in each season. In such a natural course of the sun the land is said to be prosporous.

वसन्ते कपिशाः सूर्यों ग्रीष्मे काज्चनसन्निभः।

रवेतो वर्षासु वर्णेन पाण्डुः रारदि भास्करः॥

हेमन्ते ताम्रवर्णस्तु शिशिरे लोहितो रविः।

इति वर्णाः समाख्याताः सूर्यस्य ऋतुसंभवाः।

ॠतुस्वभावजैवर्णेः सूर्यः क्षेमे सुभिक्षकृत्॥

The colour of the sun in each season is represented in the table below :

$\begin{array}{ll}\text { Season } & \text { Colour } \\ \text { Vasanta (Spring) } & \text { kapiśa (Tawny) } \\ \text { Grīṣma (Summer) } & \text { kāñana (Golden hue) } \\ \text { Varșā (Rainy) } & \text { śveta (White) } \\ \text { śarad (Autumn) } & \text { pāṇu (Pale-white) } \\ \text { Hemanta (Winter) } & \text { tāmra (Coppery red) } \\ \text { śiśira (Dew) } & \text { lohita (Reddish) }\end{array}$

The Brhatsamhit $\bar{a}^{8}$ (XXX. 22) also records the particular colour of the sun's beam during the different seasons. It also declares that each colour at twilight is beneficial in its own season and harmful if it is contrary:

\section{रिशिरादिषु वर्णाः शोण-पीत-सित-चित्र-पद्म-रुधिरनिभाः।}

प्रकृतिभवाः सन्ध्यायां स्वतो शस्ता विकृतिरन्या ॥

The Brrhatsamhitā also deals with its effects on the earth indicated by the change in the colour of the sun in various seasons. 


\section{MODERN RESEARCH :}

The spectrum of surface illumination depends upon solar elevation due to atmospheric effects, with the blue spectral component dominating during twilight before and after sunrise and sunset, respectively, and red dominating during sunrise and sunset. These effects are apparent in natural light photography where the principal source of illumination is sunlight as mediated by the atmosphere.

Also it has been established that direct sunlight has a luminous efficacy of about 93 lumens per watt of radiant flux. This is higher than the efficacy (of source) of most artificial lighting (including fluorescent), which means using sunlight for illumination heats up a room less than using most forms of artificial lighting.

\section{CONCLUSION :}

From the information available in the Purānas, it is evident that the sages had keenly observed every aspect of the sun through a period of time and have recorded it. The rays causing change in seasons, nourishing the planets and stars, intensity of the rays, their colours in different seasons have been specifically named and dealt with in detail. These can be taken up for further research and can be re-established with experiments by a modern researcher.

\section{End Notes :}

1. Sāmbapurāna, IV.5-6; 8-22

2. ibid, VII. 62; 64-69

3. ibid, VII. $46-50$

4. ibid, VII. 51-2

5. ibid, IX. 5-8

6. ibid, IX. 9-14

7. ibid, VIII. 12-13

8. Bṛhatsamhitā, XXX. 22

9. ibid, XXX. 


\section{BIBLIOGRAPHY :}

1. Sāmba Purānam, Gauri kant Jha, Academy press, Allahabad, 2011.

2. Varāhamihira's Bṛhatsamhitā, with eng.tr. M. Ramakrishna Bhat, MLBD, Delhi, 2010.

3. Kūrma Mahāpurānam, with Hindi tr. K.L. Shastri, Parimal Publications, Delhi, 2003.

4. Hazra, R.C., Studies in the Upapurānas, Sanskrit College, Calcutta, 1958.

5. Pai, G.K., Cultural history from the Kūrma Purāna, Sukrtindra Oriental Research Institute, Cochin, 1975.

All modern research data has been collected from https: / / en.wikipedia.org/wiki/Sunlight. 